\title{
Towards a Multiple Language Shift in Cameroon
}

\author{
Gilbert Tagne Safotso \\ Correspondence: Gilbert Tagne Safotso, PO Box 282 Dschang, Cameroon. \\ Received: September 4, 2021 \\ Accepted: October 9, 2021 \\ Online Published: October 26, 2021 \\ doi:10.5430/elr.v10n4p22 \\ URL: https://doi.org/10.5430/elr.v10n4p22
}

\begin{abstract}
This paper examines Cameroonians' use / attitudes to French, English, Cameroon home languages, and other variables to better project the future of those languages in Cameroon. The data analysed were collected through a questionnaire administered to 349 secondary school learners of three regions of Cameroon and 943 students of the Universities of Dschang, Douala, Buea and Maroua $(\mathrm{N}=1292)$. The findings show that a few young Cameroonians speak their mother tongues, but would like their future children to speak them and to be multilingual. This is a quite contradictory situation as those children will have nobody to acquire those languages from. An important number of young French-speaking Cameroonians would prefer English as language of instruction and would like to abandon French in future.
\end{abstract}

Keywords: French, English, Pidgin English, mother tongue, dominant, shift, education, prefer

\section{Introduction}

Wherever a language shift is observed in the world, it is slow and generally oriented towards a majority or dominant language. In a few cases like that of Rwanda, it has been as a result of political decision. In Cameroon, it can be noticed that gradually, many young people are abandoning or have already left their parents' languages to adopt either a European language or a vehicular one. The drastic change of Francophones' attitude towards English and their massive rush for it (Safotso 2012, 2015 \& 2016; Atechi 2015), is also an index of a possible shift to that language in a near or remote future. The important enrolment of francophone children in English medium schools for the past two decades amply testifies to this. Given that the vast majority of those students of francophone parentage do not speak any Cameroonian home language (Simo Bobda 2006), it can be foreseen that, because of the opportunities that English offers and the dominant role that it plays in the world today, after a few generations, French-speaking Cameroonians may, unlike Ze Amvela's (1999) prediction, naturally shift to English.

In multilingual settings like that of Cameroon many phenomena can be observed. People generally prefer to speak prestigious and dominant languages such as French, English, Pidgin English, Fufulde. In case of equal importance of some languages, there is language maintenance. When one or some of the languages spoken by a given community is/are too dominant or prestigious it leads to the abandonment or death of the minority languages. The process is slow, but it is what justifies the disappearance of some languages. In Cameroon, though not very visible, this phenomenon is gradually taking place. In the northern and south/north west regions of Cameroon, Mba (2009:551) reports that more than twenty Cameroonian home languages are dead or facing death. Those languages are distributed as follows: Far North, Baldamu, Mbedam, Zumaya; North, Dama, Pam, Ndai, Gewe, Duli, Nimbari, Oblo, Nome, Ngon, Magumi; Adamawa, Bun, Njanga, Njerep, Kasbe, Luo; North West, Busu, Bishuo, Bikya, Batomo; and South West, Ugare. This results from the fact that the younger generations reject the language of their parents. Djimeli (1997) remarked that about $40 \%$ of Cameroonian francophone families residing in urban centres have adopted French as their mother tongue. This was later confirmed by Bitja'a Kodi (2001) who reported that, in Yaounde $42.72 \%$ of Francophone parents speak French at home, $49.47 \%$ in the streets, and $50.68 \%$ at the market. $66.03 \%$ of their children speak French at home, a situation which is certainly worse twenty years later. The same study showed that $35.41 \%$ of Anglophone parents speak English at home, and $43.47 \%$ of their children do the same. At continental level, Simo Bobda (2006) points out that there is the emergence of new mother tongue in Africa. Depending on the country, that new tongue is any of the colonial masters' languages which has been indigenised and become the only language spoken by the younger generation. They speak none of the home languages, and the variety of foreign language they speak is hardly intelligible to its native speakers. It is the case with French, English, Portuguese or Spanish languages which were imposed to Africans and Asians during the colonial period. In Cameroon, Ze Amvela (1999) studied the possibility of the occurrence of language maintenance and shift with regard to the two official 
languages (English and French), which are unequally spoken by the citizens due to the important number of Francophones. He predicted that at a certain point the predominance of the French language over English in Cameroon will compel Anglophones to abandon English for it. Though French continues to dominate in the country, 22 years later, it is the reverse trend which is somewhat being observed. More and more students of Francophone parentage are rushing for English. This paper aims to throw some light at those changes and attitudes as a serious index of gradual language shift.

\section{Review of Literature}

Language shift is not a new phenomenon. Through migration and contact between people of different linguistic backgrounds it occurs almost everywhere across the world. If a language does not have enough speakers to maintain itself its remaining speakers will shift to a majority language. A number of studies have been conducted to show the various reasons for the shift and how it happens (Lieberson \& McCabe 1982; Romaine 1989; Appel \& Muysken 1993; Agyenkun 2010; Sana Nawaz et al. 2012; Kartika-Ningish \& Rose 2018; Samira Sarwat et al. 2021). Romaine (1989:38-39) remarks that a language is maintained when the number of its speakers is important and/or when it enjoys a higher status in a given society; it shifts when the community experiences a transition to a new language and dies out as a consequence of language shift. To Appel and Muyske (1993:32), shift is a neutral term in the sense that its direction can be from the minority towards the majority or more prestigious language like the case of Gujerati-speaking people in England who shifted to English. It can also involve the extension of a minority language as the case of French in Quebec, which has strengthened its position at the expense of English. Lieberson \& McCabe (1982) noted that shift between generations is sometimes very slight even in setting where a substantial portion of a mother-tongue-group acquires a second language. As example, they mentioned the case of Montreal where a sizable part of French-mother-tongue population learned English through the years, but where there is little shift because the overwhelming majority of French-bilinguals still address their offspring in French.

In a study of factors involved in the shift from Penjabi to English by Sana Narwaz et al. (2012), 100 per cent of their subjects reported that the shift was inevitable. 90 per cent of them saw English as a threat to Penjabi language and culture. 57 per cent chose English for economic reasons, and 64 per cent of the subjects saw English as sign of civilisation. Agyekum (2010) investigated language shift in Ghana from two perspectives: (1) a shift from a Ghanaian language to English, and (2) shift from one or two Ghanaian languages to a third one that has become a lingua franca in Ghana. Among the factors which contributed to the shift, he cited the economic and occupational language shift, migration and settlement patterns, exogamous marriages, government policies, political factors and religion.

\section{Methodology}

The data analysed were collected through a questionnaire (see the appendix) administered to 1292 secondary and university learners of five regions of Cameroon: the West, South West, North West, Littoral and Far North Regions. In total, 184 English-speaking learners took part in the survey (32 secondary school learners and 152 university ones). The 1108 French-speaking participants were distributed as follows: 317 secondary school subjects and 791 university students. The towns involved were those of Buea, Bamenda, Douala, Bafoussam, Dschang, Mokolo, Maroua and Mora. The respondents were put into four groups according to their age ranges. The first group comprised those aged between 10 and 16 years, roughly corresponding to Sixième-Troisième (Form I-Form 4). The second group of subjects was made up of students aged 16-20, i.e. learners from Seconde-Terminale (Form 5- Upper Sixth), the last two groups consisted of students aged 21-25 and 26-30 years. The reason for splitting the university group into two was to check if age at that level impacts the way of looking at languages. The questionnaire mediated in English and French for its full understanding comprised four questions. The first one aimed to check the language(s) spoken at home with the parents. The second verified the preferred language (s) of education, the third looked at the language(s) the subjects would prefer to abandon in future, and the last investigated the language(s) they would like their future children to speak. The questionnaire administered to the subjects of the West, South West, North West and Littoral Regions (Question 4) listed the following preferred languages for future children, from which the subjects had to select, then give the reasons for the choice: mother tongue (any), French, English, Pidgin English, other European languages. In the one administered in the Far North Region, to these languages was added Fulfulde which is the vehicular language of the region.

\section{Results}

In Cameroon, it can be observed that language shift is happening at several levels. The first level is from minority home languages to major or prestigious ones. For example, in the northern regions of the country, in the streets, many young people speak mainly Fulfulde, having forgotten about the language of their parents. Fulfulde, in addition 
to being a vehicular language is seen as that of religion, trade and the wealthy people of the region. This justifies the death of so many home languages in the region. This situation can also be observed in the South West and North West Regions where Pidgin English is the only language spoken by many youths.

The second level of language shift is from home languages to a European one. In Cameroon, this phenomenon is more observable with younger Francophones. Neither some parents nor their children speak any home language. They speak only Cameroon French, a language that Simo Bobda (2006) calls 'a new mother tongue'. With young Anglophone Cameroonians, this situation is not so alarming. A good number of them generally use their mother tongue and Pidgin English /English. Those who speak only English are a bit marginalised as not belonging to the community.

The third level of shift, and the most interesting, is the shift from French to English. In Cameroon, this kind of language shift generally concerns the younger Francophones. The rush for English for the past thirty years is an index of this. If at home they do not speak any home language with their parents but Cameroon French, and rather find more interest in English, the likelihood to abandon French for it is very high. The statistics and analysis that follow throw some light on that phenomenon. In the analysis, the informants are divided into three broad groups: (1) French-speaking subjects from southern Cameroon, (2) French-speaking informants from the Far North Region, and (3) English-speaking participants.

4.1 Southern Cameroon French-speaking Secondary School Learners' Use/Attitudes Towards Home and Foreign Languages

Depending on their age, in the southern regions of Cameroon, French-speaking secondary school learners use home and foreign languages in several ways and adopt different attitudes towards them. The section below looks at the use of those languages and behaviour to them by pupils aged 10-15 years.

\subsubsection{Use / Attitudes Towards Home and Foreign Languages By 10-15 Year-Old French-Speaking Pupils}

The following table summarises the languages used at home by southern Cameroon younger French-speaking pupils.

Table 1. 10-15 year-old southern Cameroon French-speaking pupils' language(s) used at home (N=48)

\begin{tabular}{lll}
\hline Language(s) spoken at home & Number of subjects & $\%$ \\
\hline Mother tongue & 00 & 00 \\
Mother and French & 12 & 25 \\
French & 24 & 50 \\
Pidgin English & 00 & 00 \\
English & 00 & 00 \\
\hline
\end{tabular}

It can be noted that 10-15 year-old French-speaking children in southern Cameroon mostly use French (50\%) and mother tongue plus French $(25 \%)$ at home. None of them uses only their mother tongue with their parents. Close observation reveals that those who claim to use their mother tongue and French at times only understand that tongue, but cannot speak it. So, the shift to a foreign language is already quite clear with this generation of Cameroonians. Table 2 shows their preferred language(s) of education.

Table 2. 10-15 year-old southern Cameroon French-speaking pupils' preferred language(s) of education $(\mathrm{N}=48)$

\begin{tabular}{lll}
\hline $\begin{array}{l}\text { Learners' preferred language (s) } \\
\text { of education }\end{array}$ & Number of subjects & $\%$ \\
\hline French & 24 & 50 \\
English & 18 & 37.5 \\
French and English & 00 & 00
\end{tabular}

This group of children's favourite language of education is French (50\%), followed by English. Quite surprisingly, none of them prefers a bilingual education though English and French are compulsory subjects in their school curriculum. Some of the reasons advocated for this choice include 'I am already used to it; it is better for me'. Some informants who preferred English as medium of instruction said that it is because they have some of their brothers and sisters in English-speaking countries such as the USA, Canada, South Africa, etc., and would like to visit or live in those countries one day. Table 3 below lists the languages they would prefer to abandon in future. 
Table 3. 10-15 year-old southern Cameroon French-speaking pupils' preferred language(s) to be abandoned $(\mathrm{N}=48)$

\begin{tabular}{lll}
\hline $\begin{array}{l}\text { Language (s) learners would } \\
\text { prefer to abandon in future }\end{array}$ & Number of subjects & $\%$ \\
\hline French & 18 & 37.5 \\
English & 00 & 00 \\
None & 06 & 12.5 \\
\hline
\end{tabular}

The table reveals that $37.5 \%$ of the informants said that in future they would prefer to abandon French, and $12.5 \%$ would abandon none of the two languages. This does not corroborate their answers in Table 3. It can be interpreted that they are using French as their language of instruction just because they are forced to. The small percentage of subjects $(12 \%)$ who prefer to abandon none of the languages maybe finds some interest in bilingual education. The table which follows displays the languages they would like their children to learn.

Table 4. 10-15 year-old southern Cameroon French-speaking pupils' preferred future language(s) for their children $(\mathrm{N}=48)$

\begin{tabular}{lll}
\hline $\begin{array}{l}\text { Preferred language(s) } \\
\text { for future children }\end{array}$ & Number of subjects & $\%$ \\
\hline Mother tongue & 18 & 37.5 \\
French & 18 & 37.5 \\
English & 36 & 75 \\
Pidgin English & 12 & 25 \\
Other European languages & 12 & 25
\end{tabular}

Although this group of French-speaking Cameroonian pupils do not speak any home language (see Table 1), $37.5 \%$ of them expressed their wish to see their children speak their mother tongues. This is a hopeless dream given that those future children's grandparents will not always be there to teach them the language. But interestingly, among those languages, English is $75 \%$. Thus, if they could be offered to choose only one language for their future children, the majority of these subjects would prefer English. Section 4.1.2 analyses the languages used by the informants aged 16-20 years and their attitudes to those languages.

4.1.2 Use / Attitudes Towards Home and Foreign Languages by 16-20 Year-Old French-Speaking Learners

Unlike their 10-15 year-old peers, a small percentage of French-speaking Cameroonian pupils aged 15-20 years speak their mother tongue $(16.30 \%)$ as displayed in the table below.

Table 5. 16-20 year-old southern Cameroon French-speaking learners' language(s) used at home (N=184)

\begin{tabular}{lll}
\hline Language(s) spoken at home & Number of subjects & $\%$ \\
\hline Mother tongue & 30 & 16.30 \\
Mother and French & 12 & 06.52 \\
French & 90 & 48.91 \\
Pidgin English & 00 & 00 \\
English & 00 & 00 \\
\hline
\end{tabular}

Like the preceding one, this group of Cameroonian learners mostly speaks French at home $(48.91 \%)$. Only a marginal percentage of them speak their mother tongue and French with their parents $(06.52 \%)$. The coming table slants their preferred language of instruction.

Table 6. 16-20 year-old Southern Cameroon French-speaking learners' preferred language(s) of education (N=184)

\begin{tabular}{lll}
\hline $\begin{array}{l}\text { Learners' preferred language (s) } \\
\text { of education }\end{array}$ & Number of subjects & $\%$ \\
\hline French & 72 & 39.13 \\
English & 72 & 39.13 \\
French and English & 06 & 03.26
\end{tabular}

As medium of instruction, it is interesting to note that the same number of subjects prefer English or French 
$(39.13 \%)$. But given that this group of pupils is French-speaking, it is an indication of their gradual shift to English. As with the group above, they do not find any interest in bilingual education $(03.26 \%)$. Table 7 presents the languages they would like to give up.

Table 7. 16-20 year-old southern Cameroon French-speaking learners' preferred language(s) to be abandoned (N= 184)

\begin{tabular}{lll}
\hline $\begin{array}{l}\text { Language (s) learners would } \\
\text { prefer to abandon in future }\end{array}$ & Number of subjects \\
\hline French & 90 & 48.91 \\
English & 18 & 9.78 \\
None & 24 & 13.04
\end{tabular}

It can be remarked that the percentage of subjects who would prefer to abandon French in future (48.91\%) almost matches with that of those who prefer English as language of education $(39.13 \%)$. However, the number of those who prefer French as medium of instruction or has no interest in bilingual education does not reflect their various answers here. The reasons for preferring to give up French, as the subjects reported, include 'because I hate the French people; English is more widespread; English is the language of opportunities; French is not spoken in many countries of the world'. Strikingly, no informant said that they would prefer to continue with English because it is one of the official languages of the country. The following table sketches the languages that they would prefer their children to learn/acquire.

Table 8. 16-20 year-old southern Cameroon French-speaking learners' preferred language(s) for their future children $(\mathrm{N}=184)$

\begin{tabular}{lll}
\hline $\begin{array}{l}\text { Preferred language(s) } \\
\text { for future children }\end{array}$ & Number of subjects & $\%$ \\
\hline Mother tongue & 108 & 58.69 \\
French & 114 & 61.95 \\
English & 120 & 65.21 \\
Pidgin English & 00 & 00 \\
Other European languages & 118 & 64.13 \\
\hline
\end{tabular}

It can be observed that the majority of this group of learners would prefer their children to learn English (65.21 \%), followed by other European languages $(64.13 \%)$ and French $(61.95 \%)$. Only $58.69 \%$ of them report preferring their future children to learn their mother tongue. As in the preceding group (subjects aged 10-15 years), this does not unfortunately match with their attitude to that language as only $16.13 \%$ of them speak it. It can be pointed out that although the younger generations of Cameroonians do not speak their mother tongue they regret having not learnt it. The section below analyses the attitudes of their peers of tertiary education.

4.2 Southern Cameroon French-Speaking University Students' Use/Attitudes Towards Home and Foreign Languages In general, in Cameroon the 21-25 age group corresponds to that of university studies. Section 4.2.1. discusses the French-speaking students of that group's use and attitudes towards the languages so far in question.

4.2.1 Use / Attitudes Towards Home and Foreign Languages By 21-25 Year-Old French-Speaking University Students

As Table 9 below illustrates, it can be said that age plays a key role in the use of the languages under investigation and their preferences in general as a good number of the subjects use many languages at home.

Table 9. 21-25 year-old southern Cameroon French-speaking university students' language(s) used at home (N=312)

\begin{tabular}{lll}
\hline Language(s) spoken at home & Number of subjects & $\%$ \\
\hline Mother tongue & 72 & 23.07 \\
Mother and French & 102 & 32.69 \\
French & 48 & 15.38 \\
Pidgin English & 06 & 01.92 \\
English & 12 & 03.84 \\
\hline
\end{tabular}


Though not very significant, a good number of subjects in this group report using their mother tongue (23.7\%). However, the percentage of those who claim to do so plus French remains high $(32.69 \%)$. Even the $15.38 \%$ who report using only French with their parents and the $03.84 \%$ who say using English with them should not be neglected. They should be seen as a serious index of their shift to those European languages. The next table pictures their preferred languages of instruction.

Table 10: 21-25 year-old southern Cameroon French-speaking university students' preferred language (s) of education $(\mathrm{N}=312)$

\begin{tabular}{lll}
\hline $\begin{array}{l}\text { Learners' preferred language (s) } \\
\text { of education }\end{array}$ & Number of subjects & $\%$ \\
\hline French & 114 & 36.53 \\
English & 144 & 46.15 \\
French and English & 12 & 03.84 \\
\hline
\end{tabular}

The favourite languages of education as shown by the table is English (46.15) followed by French (36.53). As with the earlier groups of subjects, they have almost no interest in bilingual education. This is rather surprising given all the speeches made in Cameroon about the advantages of that type of education. Table 11 presents the language (s) they would prefer to leave out in future.

Table 11: 21-25 year-old southern Cameroon French-speaking university students' preferred language(s) to be abandoned $(\mathrm{N}=312)$

\begin{tabular}{lll}
\hline $\begin{array}{l}\text { Language (s) learners would } \\
\text { prefer to abandon in future }\end{array}$ & Number of subjects & $\%$ \\
\hline French & 174 & 55.76 \\
English & 24 & 07.69 \\
None & 42 & 13.46
\end{tabular}

In this set, the majority of informants wish to abandon French in future (55.76\%). This quite matches their preferred language of instruction (46.15\%). As with their peers of the of the previous groups, the reasons for abandoning French for English include among others 'French is not widespread like English; French is spoken in few counties of the world; English is the language of opportunities; English is a global language'. Because of the subjects' awareness of the global position of English in the world today, it can be pointed out that the shift to that language might be more rapid. The small percentage $(13.46 \%)$ of participants who chose not to abandon any of the languages said that it is because they will better communicate in French and English and because Cameroon is a bilingual country. The coming table pictures the favourite languages for their future children.

Table 12: 21-25 year-old southern Cameroon French-speaking university students' preferred language (s) for their future children $(\mathrm{N}=312)$

\begin{tabular}{lll}
\hline $\begin{array}{l}\text { Preferred language(s) } \\
\text { for future children }\end{array}$ & Number of subjects & $\%$ \\
\hline Mother tongue & 216 & 69.23 \\
French & 186 & 59.61 \\
English & 234 & 75 \\
Pidgin English & 42 & 13.46 \\
Other European languages & 96 & 30.76 \\
\hline
\end{tabular}

Although only $23.07 \%$ of them claim to speak their home language, and $32.69 \%$ their mother tongue and French (see Table 9), a good proportion of the subjects of this group would like their children to speak their mother tongue and French, which somehow corroborates their preferred language of instruction (36.53\%). Their choice of English as their children's main language ( $75 \%$ ) is far from their claim of language of instruction (46.15\%). It should also be noted the interest of this bunch of university students in languages in general. Contrary to the earlier groups of informants, they would like their descendents to speak as many languages as possible. The reasons advocated comprise 'multilingualism opens many doors/makes you a world citizen; multilingualism makes you open-minded'. 
The following section focuses on the attitudes of their elders of 26-30 year-old towards those languages.

4.2.2 Use / Attitudes Towards Home and Foreign Languages by 26-30 Year-Old French-Speaking University Students

Like their peers of 21-20 year-old, the Table 13 reveals that a number of subjects of this groups of students speak their mother tongue $(33.33 \%)$, but a high number of them claim to speak French and mother tongue at home $(41.66 \%)$. Compared to their younger counterparts of secondary school (see Tables 1 and 5), it can be said that the age factor greatly influences the attitudes towards the parents' language (s); the younger the child is the lesser interest he/ she has in their parents' language

Table 13. 26-30 year-old southern Cameroon French-speaking university students' language(s) used at home (N=72)

\begin{tabular}{lll}
\hline Language(s) spoken at home & Number of subjects & $\%$ \\
\hline Mother tongue & 24 & 33.33 \\
Mother and French & 30 & 41.66 \\
French & 00 & 00 \\
Pidgin English & 00 & 00 \\
English & 00 & 00
\end{tabular}

It is thus interesting to observe that none of these students claim to speak French at home like their younger brothers and sisters. It is perhaps what would help some of the Cameroonian home languages survive for some time. But after this generation, it would be hard to foretell the future of those languages. The table below displays their preferred medium of instruction.

Table 14. 26-30 year-old southern Cameroon French-speaking university students' preferred language (s) of education $(\mathrm{N}=72)$

\begin{tabular}{lll}
\hline $\begin{array}{l}\text { Learners' preferred language (s) } \\
\text { of education }\end{array}$ & Number of subjects & $\%$ \\
\hline French & 30 & 41.66 \\
English & 24 & 33.33 \\
French and English & 18 & 25 \\
\hline
\end{tabular}

As the table indicates, age also plays an important role in their preferred language (s) of education. Unlike their younger peers of the preceding groups, this category of learners value French as their medium of instruction $(41.66 \%)$ as well as bilingual education (25\%). They listed the following reasons for preferring French as the language of education: 'French has always been my medium of instruction; French is one of the country's official languages; I am a francophone; it is the language I master most'. Those who opted for a bilingual education said that it is because they would like to better express themselves in Cameroon and in any French /English peaking country. Table 15 below discloses the language(s) they would like to abandon in future.

Table 15. 26-30 year-old southern Cameroon French-speaking university students' preferred language(s) to be abandoned $(\mathrm{N}=72)$

\begin{tabular}{lll}
\hline $\begin{array}{l}\text { Language (s) learners would } \\
\text { prefer to abandon in future }\end{array}$ & Number of subjects & $\%$ \\
\hline French & 30 & 41.66 \\
English & 06 & 08.33 \\
None & 18 & 25 \\
\hline
\end{tabular}

In future, the majority of this group of subjects would like to abandon French (41.66\%). This does not however match with their preferred language of education (French). So, if in Table 15 many of them claim to prefer French as their language of instruction, it is perhaps just because they have already been used to it. It would also be interesting to note their interest in keeping the two languages $(25 \%)$, which also however does not match with their wish to abandon English. Table 16 below lists the preferred language(s) for their future children. 
Table 16. 26-30 year-old southern Cameroon French-speaking university students' preferred language (s) for their future children $(\mathrm{N}=72)$

\begin{tabular}{lll}
\hline $\begin{array}{l}\text { Preferred language(s) } \\
\text { for future children }\end{array}$ & Number of subjects & $\%$ \\
\hline Mother tongue & 48 & 66.66 \\
French & 30 & 41.66 \\
English & 36 & 50 \\
Pidgin English & 18 & 25 \\
Other European languages & 12 & 16.66 \\
\hline
\end{tabular}

The table shows that the majority of the subjects would like their children to speak/learn their mother tongue (66.66). This is followed by English (50\%), French (41.66 \%), Pidgin English (25\%), and other European languages $(16.66 \%)$. So, they would like their children to be as multilingual as possible, although apart from their mother tongue, French and English they do not know any other language. This may thus be a hopeless dream as generally, children are interested in languages right from home. The next section looks at the use/attitudes of the Far North Region French-speaking secondary school learners towards the languages so far under study.

4.3 Far North Cameroon French-speaking Secondary School Learners' Use/Attitudes Towards Home and Foreign Languages

Like in the preceding sections, this set of informants will be divided into several age groups: 16-20, 20-25 and 26-30 year old. The following section investigates the attitudes of the pupils of the 16-20 year-old group.

4.3.1 Use / Attitudes Towards Home and Foreign Languages by 16-20 Year-Old Pupils

Unlike their peers of the same age group of southern Cameroon, it can be remarked that the Far North Region pupils mostly use their mother tongue at home (65.88 \%), followed by French $(42.35 \%)$ and Fufulde $(37.64 \%)$.

Table 17. 16-20 year-old Far North Cameroon French-speaking pupils' language(s) used at home $(\mathrm{N}=85)$

\begin{tabular}{lll}
\hline Language(s) spoken at home & Number of subjects & $\%$ \\
\hline Mother tongue & 56 & 65.88 \\
Fufulde & 32 & 37.64 \\
Mother and French & 00 & 00 \\
French & 36 & 42.35 \\
Pidgin English & 00 & 00 \\
English & 00 & 00
\end{tabular}

So, the popular claim that Fulfulde is the dominant language in the region is a bit challenged within the family context as only $37.64 \%$ of pupils report to speak it at home. It may be the case only in the streets as many young children continue to value their mother tongue. The percentage of those who say that they speak French at home is also quite interesting as there is assumption that the region is that of illiterate people. Table 18 shows their preferred language(s) of instruction.

Table 18. 16-20 year-old Far North Cameroon French-speaking pupils' preferred language(s) of education (N=85)

\begin{tabular}{lll}
\hline $\begin{array}{l}\text { Learners' preferred language (s) } \\
\text { of education }\end{array}$ & Number of subjects & $\%$ \\
\hline French & 36 & 42.35 \\
English & 12 & 14.11 \\
French and English & 12 & 14.11 \\
\hline
\end{tabular}

The preferred medium of instruction of this group of subjects is French $(42.35 \%)$. The same number of them value bilingual education (French-English). But it should be pointed out that this percentage (14.11\%) of pupils who value it is quite insignificant and somewhat testifies to the failure of the bilingualism policy in Cameroon. Many subjects have so far been having little interest in it because there is no incentive in embarking in such studies. The next table 
lists the language(s) they would like to give up in future.

Table 19. 16-20 year-old Far North Cameroon French-speaking pupils' preferred language(s) to be abandoned $(\mathrm{N}=85)$

\begin{tabular}{lll}
\hline $\begin{array}{l}\text { Language (s) learners would } \\
\text { prefer to abandon in future }\end{array}$ & Number of subjects & $\%$ \\
\hline French & 44 & 51.76 \\
English & 24 & 28.23 \\
None & 08 & 09.41 \\
\hline
\end{tabular}

The majority of these pupils said that in the long run they would prefer to leave out French (51.76\%). Only $28.23 \%$ of them wished to give up English. This high proportion of those desiring to abandon English in future is quite consistent in all the groups (see Tables 3, 7, 10, 15). The various reasons for abandoning French by this group of subjects include 'I am fed up with that language; Cameroon was colonised by France; Cameroon is exploited by France; French is not a language of opportunities, etc.' With these ideas against the French and French language in mind, it can be deduced that the shift to English by these pupils is seriously on the way. Table 20 displays the language (s) they would like their children to learn/speak.

Table 20. 16-20 year-old Far North Cameroon French-speaking pupils' preferred language(s) for their future children $(\mathrm{N}=85)$

\begin{tabular}{lll}
\hline $\begin{array}{l}\text { Preferred language(s) } \\
\text { for future children }\end{array}$ & Number of subjects \\
\hline Mother tongue & 52 & 61.17 \\
Fufulde & 24 & 26.23 \\
French & 48 & 56.47 \\
English & 40 & 47.05 \\
Pidgin English & 12 & 14.11 \\
Other European languages & 12 & 14.11 \\
\hline
\end{tabular}

The table pictures that these pupils would like their children to be multilingual with mother tongue $(61.17 \%)$ and French $(56.47 \%$ ) being their best languages. But in the ranking, English also occupies a good position (47.05 \%). Section 4.4. surveys the attitudes of their elder counterparts of tertiary education towards the languages in question.

\subsection{Far North Cameroon French-Speaking University Students' Use/Attitudes Towards Home and Foreign Languages}

As in the study of the attitudes of the southern Cameroon French-speaking university students, this bunch of informants is divided into two age groups: 21-25 and 26-30 year-old.

\subsubsection{Use / Attitudes Towards Home and Foreign Languages By 21-25 and 26-30 Year-Old University Students}

The following table lists the language spoken /used at home by both groups of subjects.

Table 21. 21-25 and 26-30 year-old Far North Cameroon university students' language(s) used at home

\begin{tabular}{lllll}
\hline $\begin{array}{l}\text { Language(s) spoken at } \\
\text { home }\end{array}$ & $\begin{array}{l}21-25 \text { year-old } \\
\mathrm{N}=165\end{array}$ & $\%$ & $\begin{array}{l}26-30 \text { year-old } \\
\mathrm{N}=240\end{array}$ & $\%$ \\
\hline Mother tongue & 76 & 46.06 & 48 & 20 \\
Fufulde & 28 & 19.06 & 08 & 03.33 \\
Mother and French & 20 & 12.12 & 00 & 00 \\
French & 48 & 29.09 & 30 & 15 \\
Pidgin English & 00 & 00 & 00 & 00 \\
English & 00 & 00 & 00 & 00 \\
\hline
\end{tabular}

It can be noted that both groups of informants use many languages at home, namely mother tongue, Fulfulde and 
French. But the percentage of students aged 21-25 who use those languages is higher than that of their elders aged 26-30: mother tongue (46.06 \% against 20\%); Fufulde (19.06\% against $03.33 \%$ ) and French $(29.09 \%$ against $15 \%$ ). These percentages are rather striking since normally it is the oldest subjects who are supposed to speak more mother tongue and Fulfulde at home. It can also be noticed that a good number of informants aged 21-25 speak French and mother tongue with their parents. Table 22 summarises their preferred languages of education.

Table 22. 21-25 and 26-30 year-old Far North Cameroon university students' preferred language(s) of education

\begin{tabular}{lllll}
\hline $\begin{array}{l}\text { Learners' preferred } \\
\text { language (s) of education }\end{array}$ & $\begin{array}{l}21-25 \text { year-old } \\
\mathrm{N}=165\end{array}$ & $\%$ & $\begin{array}{l}26-30 \text { year-old } \\
\mathrm{N}=240\end{array}$ & $\%$ \\
\hline French & 100 & 60.60 & 44 & 18.33 \\
English & 28 & 16.96 & 12 & 05 \\
French and English & 16 & 09.69 & 14 & 05.33 \\
\hline
\end{tabular}

As in the preceding table, the various figures are quite striking. The younger subjects better prefer French $(60.60 \%)$ and English (16.96) as their language of instruction while their elders value French (18.33\%). In both groups, it is an insignificant number of subjects who appreciate bilingual education. The table below shows the language(s) that they would like to abandon in future.

Table 23. 21-25 and 26-30 year-old Far North Cameroon university students' preferred language(s) to be abandoned

\begin{tabular}{lllll}
\hline $\begin{array}{l}\text { Language (s) learners would } \\
\text { prefer to abandon in future }\end{array}$ & $21-26$ year-old & $\%$ & $\begin{array}{l}26-30 \text { year-old } \\
\mathrm{N}=240\end{array}$ & $\%$ \\
\hline French & $\mathrm{N}=165$ & & 28 & 11.66 \\
English & 80 & 46.48 & 28 & 21.66 \\
None & 24 & 14.54 & 52 & 01.66
\end{tabular}

To the 21-26 year-old informants, the first language they would like to leave out is French (46.48\%). Those aged 26-30 would rather prefer to give up English. In both groups only a negligible number of subjects reported that they would like to continue with the two languages. It should be pointed out that this rejection of French-English bilingualism has been running throughout the study by an overwhelming majority of the subjects. Table 24 below lists the various languages the two groups of students concerned here would like their future children to learn/ use.

Table 24. 21-25 and 26-30 year-old Far North Cameroon university students' preferred language(s) for their children

\begin{tabular}{lllll}
\hline $\begin{array}{l}\text { Preferred } \\
\begin{array}{l}\text { language(s) } \\
\text { future children }\end{array}\end{array}$ & $\begin{array}{l}21-26 \text { year-old } \\
\mathrm{N}=165\end{array}$ & $\%$ & $\begin{array}{l}26-30 \text { year-old } \\
\mathrm{N}=240\end{array}$ & $\%$ \\
\hline Mother tongue & 104 & 63.03 & 56 & 23.33 \\
Fufulde & 16 & 09.69 & 00 & 00 \\
French & 88 & 53.33 & 32 & 13.33 \\
English & 84 & 50.90 & 44 & 18.33 \\
Pidgin English & 12 & 07.27 & 00 & 00 \\
$\begin{array}{l}\text { Other European } \\
\text { languages }\end{array}$ & 00 & 00 & 08 & 03.33 \\
\hline
\end{tabular}

In the two groups, the majority of informants would like their offspring to be multilingual. To the subjects aged $21-26$, the first language they wish their children to speak is mother tongue $(63.63 \%)$, followed by French $(53.33 \%)$ and English (50.90\%). Those aged 26-30 reported preferring their children to speak their mother tongue (23.33\%), followed by English $(18.33 \%)$ and French $(13.33 \%)$. Although Fufulde is quite popular in the streets of the Far North Region it is very striking to see its restricted use within the family setting and the wish of the young people of the region not to see their future children speak it. The section which follows studies the attitudes of English-speaking Cameroonian secondary school learners towards the languages so far under investigation. 


\subsection{English-Speaking Cameroonian Secondary School Learners' Use/Attitudes Towards Home and Foreign Languages}

The group of learners concerned here is aged 16-20 years. Table 25 discloses the language(s) they speak /use at home.

Table 25. 16-20 year-old English-speaking Cameroonian learners' language(s) used at home $(\mathrm{N}=32)$

\begin{tabular}{lll}
\hline Language(s) spoken at home & Number of subjects & $\%$ \\
\hline Mother tongue & 12 & 37.5 \\
Mother and Pidgin English & 07 & 21.87 \\
English & 00 & 00 \\
Pidgin English & 08 & 25 \\
French & 00 & 00
\end{tabular}

At home, an important number of the subjects use their mother tongue (37.5\%), followed by Pidgin English (25\%) and mother tongue plus Pidgin English $(21.87 \%)$. This percentage of pupils who use Pidgin English somewhat testifies to the popularity of that language in the English-speaking regions of Cameroon. The fact that no subject claims to speak English at home is quite striking, given that it is their language of instruction. The next table sheds light on their preferred language of instruction.

Table 26.16-20 year-old English-speaking Cameroonian learners' preferred language(s) of education $(\mathrm{N}=32)$

\begin{tabular}{lll}
\hline $\begin{array}{l}\text { Learners' preferred language (s) } \\
\text { of education }\end{array}$ & Number of subjects & $\%$ \\
\hline French & 00 & 00 \\
English & 32 & 100 \\
French and English & 00 & 00 \\
\hline
\end{tabular}

The table indicates that $100 \%$ of the informants prefer English as their language of education. So, neither French as language of instruction, nor bilingual education is important to them. Table 27 reveals the language (s) they would like to give up in future.

Table 27. 16-20 year-old English-speaking Cameroonian learners' preferred language(s) to be abandoned $(\mathrm{N}=32)$

\begin{tabular}{lll}
\hline $\begin{array}{l}\text { Language (s) learners would } \\
\text { prefer to abandon in future }\end{array}$ & Number of subjects & $\%$ \\
\hline French & 27 & 83.37 \\
English & 00 & 00 \\
None & 00 & 00 \\
\hline
\end{tabular}

The vast majority of these subjects would prefer to abandon French in time to come. This correlates very well their answers in Table 26. Some of the reasons they gave for preferring that option is that English is the language they master, or that French is of little use to them. Table 28 slants the language(s) that they would like their future children to speak/use.

Table 28.16-20 year-old English-speaking Cameroonian learners' preferred language(s) for their future children $(\mathrm{N}=$ 32)

\begin{tabular}{lll}
\hline $\begin{array}{l}\text { Preferred language(s) } \\
\text { for future children }\end{array}$ & Number of subjects & $\%$ \\
\hline Mother tongue & 18 & 56.25 \\
French & 08 & 25 \\
English & 24 & 75 \\
Pidgin English & 06 & 18.75 \\
Other European languages & 24 & 75 \\
\hline
\end{tabular}


Some of the answers contained in this table rather contradict those provided in the preceding ones. The majority of the subjects report preferring their offspring to speak English $(75 \%)$ and their mother tongue $(56.25 \%)$. It is thus hard to understand why some of them would like them to speak French $(25 \%)$ that they reject, and mother tongue that few of them speak. The reasons for preferring their children to be multilingual include among others that it will make them be open-minded and will expose them to other cultures for a better social integration. The last section which follows investigates the attitudes of their peers of tertiary education.

\subsection{English-Speaking Cameroonian University Students'Use/Attitudes Towards Home and Foreign Languages}

Like their French-speaking counterparts of other regions of Cameroon, the subjects here have been divided into two broad age groups: 21-25 and 26-30 year-old. The table below clarifies the language(s) they use/speak at home.

Table 29. 21-25 and 26-30 year-old English-speaking university students' language(s) used at home

\begin{tabular}{lllll}
\hline $\begin{array}{l}\text { Language(s) spoken at } \\
\text { home }\end{array}$ & $\begin{array}{l}21-26 \text { year-old } \\
\mathrm{N}=96\end{array}$ & $\%$ & $\begin{array}{l}26-30 \text { year-old } \\
\mathrm{N}=56\end{array}$ & $\%$ \\
\hline Mother tongue & 18 & 18.75 & 18 & 18.75 \\
Mother and French & 06 & 06.25 & 06 & 06.25 \\
French & 06 & 06.25 & 06 & 06.25 \\
Pidgin English & 18 & 18.75 & 18 & 18.75 \\
English & 12 & 12.5 & 12 & 12.5 \\
$\begin{array}{llll}\text { Mother tongue } \\
\text { Pidgin E }\end{array}$ & 06 & 06.25 & 06 & 06.25 \\
\hline
\end{tabular}

Unlike their younger peers of secondary school studied in Section 4.5 above who reported speaking only their mother tongue and Pidgin English at home, both groups of subjects involved here claim to speak so many languages with their parents. It should be observed that for each of the concerned languages just a small number of informants speak it. The $18.75 \%$ of the subjects who report speaking their home language and Pidgin English in both groups somewhat testifies to the importance they give to those languages as noted with the preceding group. Table 30 shows their favourite medium of instruction.

Table 30. 21-25 and 26-30 year-old English-speaking university students' preferred language(s) of education

\begin{tabular}{lllll}
\hline $\begin{array}{l}\text { Learners' } \\
\text { language (s) } \\
\text { of education }\end{array}$ & preferred & $\begin{array}{l}21-25 \text { year-old } \\
\mathrm{N}=96\end{array}$ & $\%$ & $\begin{array}{l}26-30 \text { year-old } \\
\mathrm{N}=56\end{array}$ \\
\hline French & 18 & 18.75 & 06 & 10.71 \\
English & 56 & 58.33 & 36 & 64.24 \\
French and English & 00 & 00 & 00 & 00 \\
\hline
\end{tabular}

Unlike their junior peers of secondary school, both groups of subjects here prefer English and French as their languages of instruction. Although the percentage of those who claim French as their second medium of education is quite low in the two groups (18.75\% and $10.71 \%$ ), in the context of Cameroon this is laudable. Unfortunately, this may be interpreted as a constraint by the bilingual training unit which is compulsory at university level in the country. Their aversion for bilingual education clearly confirms this. The following table lists the language(s) they would like to abandon in future.

Table 31. 21-25 and 26-30 year-old English-speaking university students' preferred language(s) to be abandoned

\begin{tabular}{lllll}
\hline $\begin{array}{l}\text { Language (s) } \\
\text { would prefer to } \\
\text { abandon in future }\end{array}$ & $\mathrm{N}=96$ & $\%$ & $\begin{array}{l}26-30 \text { year-old } \\
\mathrm{N}=56\end{array}$ & $\%$ \\
\hline French & 74 & & & 100 \\
English & 06 & 77.03 & 56 & 00 \\
None & 12 & 06.25 & 00 & 00 \\
\hline
\end{tabular}

The information provided in this table matches very well with the one contained in Table 30 above. An 
overwhelming majority of the subjects of both groups wish to give up French in future (i.e. after university). Only an insignificant number of those aged 21-25 said that they would prefer to abandon none of the languages, perhaps because they still have bilingual training as a compulsory subject to complete. The last table below displays the languages they would like their future children to use/speak.

Table 32. 21-25 and 26-30 year-old English-speaking university students' preferred language (s) for their future children

\begin{tabular}{lllll}
\hline $\begin{array}{l}\text { Preferred language(s) } \\
\text { for future children }\end{array}$ & $\begin{array}{l}21-26 \text { year-old } \\
\mathrm{N}=96\end{array}$ & $\%$ & $\begin{array}{l}26-30 \text { year-old } \\
\mathrm{N}=56\end{array}$ & $\%$ \\
\hline Mother tongue & 60 & 62.5 & 42 & 75 \\
French & 42 & 43.75 & 24 & 42.85 \\
English & 66 & 68.75 & 42 & 75 \\
$\begin{array}{l}\text { Pidgin English } \\
\text { Other European }\end{array}$ & 18 & 18.75 & 06 & 10.71 \\
languages & 18 & 18.75 & 18 & 31.14 \\
\hline
\end{tabular}

It can noticed that the majority of informants of the two groups wish their future offspring to be multilingual. This has already been noted with all the earlier groups of subjects. English is the first language they would like them to speak $(68.75 \%$ and $75 \%$ ), followed by mother tongue (62.5\% and $75 \%)$, French $(43.75 \%$ and $42.85 \%)$ and other European languages $(18.75 \%$ and $31.14 \%$ ). It is rather surprising to see that just a little percentage of the informants would like their children to speak Pidgin English (18.75\% and $10.75 \%)$.

\section{Conclusion}

In conclusion, young Cameroonians of secondary school and university levels have several attitudes towards the use of their mother tongues, French, English and other European languages. At home, the vast majority of French-speaking Cameroonians of secondary school level (aged 10-20) mostly use French with their parents. A marginal number of them speak French and mother tongue with the parents, but most of the time they simply understand their mother tongue and cannot speak it. About 25\% of their elders aged 21-30 (university) continue to use their home languages, but still mostly switch to French when speaking to their parents. It is in the northern region that about $50 \%$ of the young people of the 16-20 years age group continue to speak their home language. About $60 \%$ of their elders of the same region continue to value their home languages. One of the most striking facts is that Fufulde which is the vehicular language of that region is less spoken within the family context. Unlike their French-speaking fellow countrymen, a little percentage of young English-speaking Cameroonians continue to value their home languages $(25.08 \%)$ and Pidgin English $(20.83 \%)$ within the family context.

As to the favourite language (s) of education, most French-speaking Cameroonians of all ages reported preferring English for several reasons including that the French colonised and continue to exploit Cameroon, and their language is limited; that English opens the window to the world and is the language of opportunities. Almost all the young English-speaking Cameroonians reported valuing English as their medium of instruction. Only a marginal number of subjects of all the groups concerned in the study saw some interest in bilingual (French-English) education (08.33\%), which testifies to failure of French-English bilingualism policy in Cameroon.

Concerning the foreign language (s) to be abandoned in future, $45.95 \%$ of young French-speaking Cameroonian from the south and $36.63 \%$ of them from the Far North said they will throw away French. $100 \%$ of their English-speaking counterparts also reported that they will give up French and continue only with English. The preference of all the study's subjects to have multilingual future children quite contradicts their attitudes towards the languages investigated. One cannot report that they wish their future offspring to speak a mother tongue that they do not use themselves, and to speak a French language that they do not like for several reasons. Nevertheless the various statistics provided by this study have shown that in Cameroon a multiple language shift is seriously on the way: (1) the shift from home languages to French and English, (2) the shift from home language to vehicular languages such as Pidgin English and Fufulde, and (3) more importantly, the gradual shift of French-speaking Cameroonians to English through education. 


\section{References}

Agyekum, K. K. (2010). Language Shift: A Case Study of Ghana. Sociolinguistic Studies, 3(3), $381-403$. https://doi.org/10.1558/sols.v3i3.381

Appel, R., \& Muysken, P. C. (1993). Language Contact and Bilingualism. London: Edward Arnold.

Atechi, S. N. (2015). The Emergence of Cameroon Francophone English and the Future of English in Cameroon. British Journal of English Linguistics, 3(3), 23-33.

Bitja'a Kodi, Z. D. (2001). Attitudes et représentations linguistiques à Yaoundé. African Journal of Applied Linguistics, 2, 100-124.

Djimeli, S. R. (1997). Le français et le plurilinguisme au Cameroun. Unpublished MA Dissertation. Yaounde: University of Yaounde I.

Kartika N. H., \& Rose, D. (2018). Language shift. Analysing language use in multilingual classroom. Functional Linguistics, 5(9),1-22. https://doi.org/10.1186/s40554-018-0061-0

Lieberson, S. J., \& McCabe, E. J. (1982). Domains of language usage and mother tongue shift in Nairobi. International Journal of the Sociology of Language, 33, 83-94. https://doi.org/10.1515/ijsl.1982.34.83

Mba, G. (2009). Langues et gestion des langues au Cameroun. In Eboussi Boulaga ed). L'Etat du Cameroun 2008. Yaounde: Prescriptors \& editions terroirs, pp.551-569.

Romaine, S. (1989). Bilingualism. Oxford: Basil Blackwell Ltd.

Safotso, G. T. (2012). Aspects of Cameroon Francophone English Phonology. Theory and Practice in Language Studies, 2(2), 2471-2477. https://doi.org/10.4304/tpls.2.12.2471-2477

Safotso, G. T. (2015). A Study of the Phonological Features of Cameroon Francophone English. Saarbrücken: Scholars' Press.

Safotso, G. T. (2016). Cameroon Francophone English: An Atypical Example to Moag's and Schneider's Models. British Journal of English Linguistics, 4(5), 1-10.

Samira, S., Haris, K., N. Q., \& Muhammed, A. (2021). Language shift and maintenance: A case study of Pakistani-American Family. International Journal of English Linguistics, 11(1), 86-92. https://doi.org/10.5539/ijel.v11n1p86

Sana, N., Ayesha U., Fatima A., \& Muhamed, R. (2012). Language Shift: An Analysis of Factors Involved in Language Shift. Global Journal of Human Social Science Linguistics \& Education, 12(10), 73-80.

Simo Bobda, A. (2006). The emergence of "new mother tongue" in Africa and its Implications: The Example of Cameroon. In van der Walt ed. (2006), Living through Languages- An African Tribute to René Driven. Stellembosch: Sun Press, pp. 55-69.

Ze Amvela, E. (1999). English and French in Cameroon: a Case study of Language Maintenance and shift. In Echu, G \& Grundstrom, A. W. eds. (1999), Official Bilingualism and Linguistic Communication in Cameroon. New York. Peter Lang, pp. 133-145.

\section{Acknowledgements}

I wish to thank all those who helped me administer my questionnaire in the various towns/schools and universities. My special thanks go to Dr. Williams F. Yogno Tebeko and Ms Askiya Ogza who administered the questionnaire at the University of Maroua and in the towns of Mokolo and Mora. To all my postgraduate students who accepted to help me during their Easter holidays in Douala, Buea and Bamenda, my immense gratitude. 


\section{Appendix}

\section{STUDENTS' QUESTIONNAIRE}

Please, fill in this questionnaire. The information supplied is intended for research and will serve that purpose only. Veuillez remplir ce questionnaire. Les informations fournies serviront pour la recherche et ne serviront uniquement qu'à ce propos.

In all the sections tick the appropriate answer (s). Dans toutes les sections cochez la /les réponse $(s)$ appropriée $(s)$.

1. Personal background / Informations personnelles

I am a francophone/ Je suis un francophone $\square \quad$ I am an Anglophone/ Je suis un anglophone $\square$

2. Age/ âge: 10-15 years/ans $\square$ 16-20 years /ans $\square 21-25$ years/ ans $\square \quad 26-30$ years/ans $\square$

3. What languages do you speak with your parents and family at home?/ Quelles langues parlez-vous avec vos parents et la famille à la maison?

Mother tongue/ Langue maternelle $\square$ Fufulde $\square$ French / français $\square$ English / anglais $\square$ Pidgin $\square$

4. Which language of instruction do you prefer? Quelle langue d'instruction préférez-vous? French / français English / anglais $\square$

Why ? pourquoi?

5. In future, would you prefer to abandon French or English? Dans l'avenir souhaiterezvous abandonner le français ou l'anglais? French / français $\square \quad$ English / anglais $\square$

Why ? pourquoi?

6. What languages would you like your children to speak? Tick as many answers as possible. Quelles langues préfèrerez-vous que vos enfants parlent? Cochez autant de réponses possibles. Mother tongue / langue maternelle $\square \quad$ Fufulde $\square$ French/ français $\square$

English / anglais $\square \quad$ Pidgin English $\square \quad$ Other European languages/ Autres langues européennes $\square$

Why ? / pourquoi?

\section{Copyrights}

Copyright for this article is retained by the author(s), with first publication rights granted to the journal.

This is an open-access article distributed under the terms and conditions of the Creative Commons Attribution license (http://creativecommons.org/licenses/by/4.0/). 